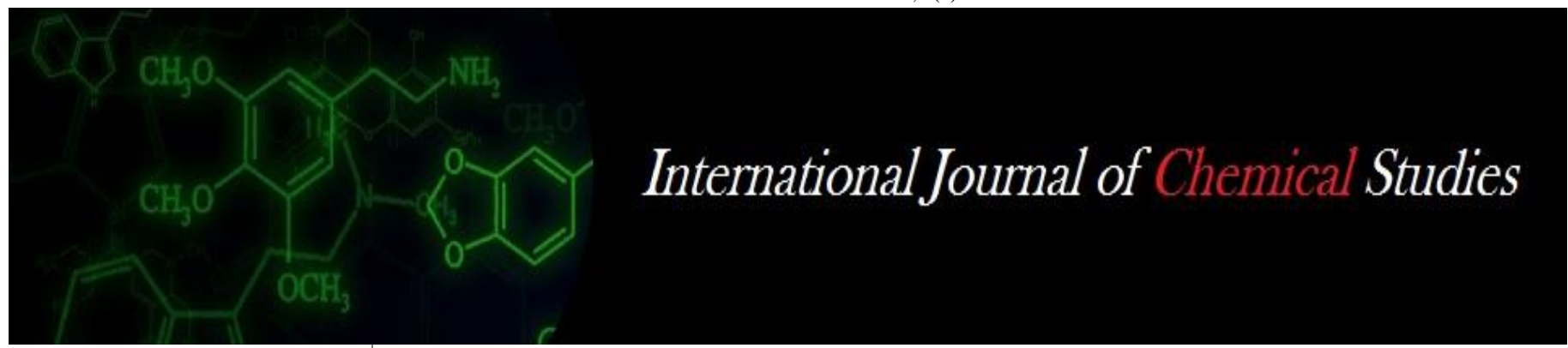

P-ISSN: 2349-8528

E-ISSN: 2321-4902

IJCS 2020; 8(1): 1224-1227

(C) 2020 IJCS

Received: 04-11-2019

Accepted: 06-12-2019

\section{NR Kadge}

Horticulture Section, College of Agriculture, Dr. Panjabrao Deshmukh Krishi Vidyapeeth, Akola, Maharashtra, India

\section{SR Dalal}

Horticulture Section, College of Agriculture, Dr. Panjabrao Deshmukh Krishi Vidyapeeth, Akola, Maharashtra, India

\section{RP Raut}

Horticulture Section, College of Agriculture, Dr. Panjabrao Deshmukh Krishi Vidyapeeth, Akola, Maharashtra, India
Corresponding Author: NR Kadge

Horticulture Section, College of Agriculture, Dr. Panjabrao Deshmukh Krishi Vidyapeeth, Akola, Maharashtra, India

\section{Effect of lime blended bael syrup on quality and sensory evaluation}

\author{
NR Kadge, SR Dalal and RP Raut
}

DOI: https://doi.org/10.22271/chemi.2020.v8.i1q.8417

\begin{abstract}
An investigation on "Effect of different recipes on storage of lime blended Bael syrup" was conducted at the Post-Harvest Technology Laboratory, Section of Horticulture, College of Agriculture, Dr. Panjabrao Deshmukh Krishi Vidyapeeth, Akola during the year 2014-2015 and with the objectives to assess the chemical changes of lime blended Bael syrup under ambient storage condition and to find out the suitable recipe for preparation of lime blended Bael syrup. The experiment was laid out in Completely Randomized Design with three replications and ten treatments. The lime blended Bael syrup was filled in $200 \mathrm{ml}$ pre-sterilized glass bottles and stored at ambient storage conditions. From the finding it was observed that, there was decrease in ascorbic acid. Minimum changes in ascorbic acid in Bael syrup was observed when prepared with using 30 per cent Bael pulp blended with 10 per cent lime juice. The Bael syrup prepared with using 30 per cent Bael pulp blended with 10 per cent lime juice when stored at ambient storage condition remain better without spoilage upto 120 days. Similarly the Bael syrup prepared with using 30 per cent Bael pulp blended with 10 per cent lime juice and stored at ambient storage condition secured the highest score for colour, flavor, taste and overall acceptability as compared to other recipes.
\end{abstract}

Keywords: Bael syrup, lime juice, Bael pulp, ambient storage

\section{Introduction}

Bael (Aegle marmelos L. Correa) belongs to the family Rutaceae, It is an important indigenous fruit of India. The Bael fruit is one of the most nutritious fruits. According to Gopalan et al. (1971) $^{[6]}$, it contains $61.5 \mathrm{~g}$ water, $1.8 \mathrm{~g}$ protein, $0.39 \mathrm{mg}$ fat, $1.7 \mathrm{~g}$ minerals, $31.8 \mathrm{~g}$ carbohydrates, $55 \mathrm{mg}$ carotene, $0.13 \mathrm{mg}$ thiamine, $1.19 \mathrm{mg}$ riboflavin, $1.1 \mathrm{mg}$ niacin and $8 \mathrm{mg}$ vitamin $\mathrm{C}$ per $100 \mathrm{~g}$ of edible portion. No other fruit has such a high content of riboflavin. A fair amount of pectin is found in Bael. The percentage of pectin on fresh fruit weight basis is 2.66 (Roy and Mujumdar, 1989) ${ }^{[14]}$. Marmelosin is most probably the therapeutically active principal of Bael fruit. It has been isolated as a colourless crystalline compound (Dixit and Dutta, 1932) ${ }^{[3]}$.

The fresh form of Bael fruit is generally not consumed due to their high astringency and thus, fruit during their peak harvesting season go as waste due to limited usage. But, it has great potential in processed form. The work on processed form of Bael in this region is scanty. Thus scientific approach in preparation and preservation of Bael processed products like lime blended Bael syrup, ready to serve beverages, etc. is required. Earlier, workers have explored the possibilities of utilizing Bael fruit beverages for the preparation juice and syrup. Although alone Bael fruit syrup prepared, have poor consumer acceptance. Keeping all these views into consideration, the experiment was undertaken on "Effect of different recipes on storage of lime blended Bael syrup". This would result in emerging suitable technology for utilization by the processing industries.

\section{Materials and Methods}

Well ripened Bael fruit will be harvested from the Main Garden, Department of Horticulture, Dr. P.D.K.V., Akola. The collected fruits were washed thoroughly with clean water. Pulp was extracted from fruits by scooping. Water was added to the pulp equal to the weight of the pulp followed by mixing, heating at $80{ }^{\circ} \mathrm{C}$ for 1 minute and then passing through muscline cloth to separate seeds and fiber. Thus extracted pulp was used for preparation of Bael syrup with following recipe. 
Bael pulp: As per treatment

Lime juice: As per treatment

Sugar: $2.5 \mathrm{~kg}$ per $\mathrm{kg}$ of pulp

Sodium Benzoate: 250 ppm

Beal syrup was filled into the pre-sterilized bottles of $200 \mathrm{ml}$ capacity and sealed air tight using crown cork and it was stored as per treatment for further observations.

An experiment was conducted in Completely Randomized Design comprise ten different recipes of syrup as treatments. Bael syrup prepared as per treatments was filled in $200 \mathrm{ml}$ pre-sterilized glass bottles and stored at ambient storage condition. These treatments were replicated three time. The prepared syrup was analyzed for physico-chemical characteristics and assessed for its acceptability by organoleptic evaluation at 120 days of storage. The observation on ascorbic acid, colour, flavor, taste and overall acceptability were recorded at initial, 90 and 120 days of storage.

Ascorbic acid content was estimated by using 2,6dichlorophenol indophenols dye as reported by Ranganna (1986) ${ }^{[11]}$. Bael syrup was evaluated for sensory qualities viz. colour, flavour, taste and overall acceptability each attribute was given a separate score of 9 point hedonic scale according to the method reported by Amerine et al. (1965) ${ }^{[1]}$.

\section{Results and Discussion}

\subsection{Ascorbic acid}

The data in respect of ascorbic acid content of lime blended Bael syrup as influenced by different recipes at ambient storage condition was recorded upto 120 days of storage are presented in Table 1. There was decrease in ascorbic acid of lime blended Bael syrup during storage. The decrease in ascorbic acid of lime blended Bael syrup during storage was probably due to the fact that ascorbic acid being sensitive to oxygen, light and heat was easily oxidized in presence of oxygen by both enzymatic and non-enzymatic catalyst. Minimum decrease (from 16.87 to $16.35 \%$ ) in ascorbic acid at 120 days of storage was observed in treatment $\mathrm{T}_{7}(30 \% \mathrm{Bael}$ pulp $+10 \%$ lime juice). Similar result were also reported by Garg et al. (2014) ${ }^{[4]}$ reported that, there was decrease in ascorbic acid in Bael wine during 12 month of storage period. Rathod et al. (2014) ${ }^{[13]}$ reported that, there was decrease in ascorbic acid during advancement of storage period of Bael RTS blending with aonla.

\subsection{Colour}

The data in respect of colour of lime blended Bael syrup as influenced by different recipes at ambient storage condition was recorded upto 120 days of storage are presented in Table 1. The data exhibited that, the colour score of lime blended Bael syrup was decreased during storage period. The decrease in colour of lime blended Bael syrup during storage can be attributed to catalytic effect of light on deteriorative changes as the bottles were transparent. Minimum decrease (from 9.4 to 8.9$)$ in colour score was noticed in treatment $\mathrm{T}_{7}(30 \% \mathrm{Bael}$ pulp $+10 \%$ lime juice). The lime blended Bael syrup prepared with using 30 per cent Bael pulp blended with 10 per cent lime juice had highest colour score for ambient storage period. Similar results were reported by (Waskar and Khurdiya, 1987); Ranote et al. (1995) ${ }^{[15,12]}$ observed decline colour score for ambient storage as compared to cold storage due to catalytic effect of light on deteriorative changes as the pouches were transparent.

Table 1: Effect of storage conditions on ascorbic acid and colour score

\begin{tabular}{|c|c|c|c|c|c|c|c|c|}
\hline \multirow{3}{*}{ Treatment } & \multicolumn{3}{|c|}{$\begin{array}{c}\text { Ascorbic acid } \\
\text { (mg/100 ml juice) }\end{array}$} & \multirow{3}{*}{$\begin{array}{l}\text { Change in ascorbic acid } \\
(\mathrm{mg} / \mathbf{1 0 0} \mathrm{ml} \text { juice })\end{array}$} & \multirow{2}{*}{\multicolumn{3}{|c|}{\begin{tabular}{|c|} 
Colour score \\
Storage period (days)
\end{tabular}}} & \multirow{3}{*}{ Total change in colour score } \\
\hline & \multicolumn{3}{|c|}{ Storage period (days) } & & & & & \\
\hline & Initial & $9^{\text {th }}$ & $120^{\text {th }}$ & & Initial & $\mathbf{9 0}^{\text {th }}$ & $120^{\text {th }}$ & \\
\hline $\mathrm{T}_{1} 25 \%$ Bael Pulp + 5\% lime Juice & 15.87 & 14.77 & 14.59 & 01.28 & 9.0 & $*$ & $*$ & 1.1 \\
\hline $\mathrm{T}_{2} 25 \%$ Bael Pulp + 7.5\% Lime Juice & 15.96 & 14.95 & 14.83 & 01.13 & 9.0 & $*$ & $*$ & 1.0 \\
\hline $\mathrm{T}_{3} 25 \%$ Bael Pulp + 10\% Lime Juice & 16.52 & 16.07 & 15.98 & 0.54 & 9.3 & 9.0 & 8.6 & 0.7 \\
\hline $\mathrm{T}_{4} 25 \%$ Bael Pulp + $12.5 \%$ Lime Juice & 16.81 & 15.35 & 15.19 & 01.62 & 9.2 & 8.8 & 8.4 & 0.8 \\
\hline $\mathrm{T}_{5} 30 \%$ Bael Pulp + 5\% Lime Juice & 15.95 & 15.23 & 15.09 & 0.86 & 9.1 & $*$ & $*$ & 0.9 \\
\hline T $630 \%$ Bael Pulp + 7.5\% Lime Juice & 16.27 & 15.54 & 15.44 & 0.83 & 9.1 & 7.8 & $*$ & 1.3 \\
\hline $\mathrm{T}_{7} 30 \%$ Bael Pulp + 10.\% Lime Juice & 16.87 & 16.42 & 16.35 & 0.52 & 9.4 & 9.2 & 8.9 & 0.5 \\
\hline $\mathrm{T}_{8} 30 \%$ Bael Pulp + $12.5 \%$ Lime Juice & 16.95 & 15.92 & 15.78 & 01.17 & 9.3 & 8.7 & 8.4 & 0.9 \\
\hline $\mathrm{T}_{9} 25 \%$ Bael Pulp & 15.48 & 14.87 & 14.45 & 01.03 & 8.9 & $*$ & $*$ & 1.4 \\
\hline $\mathrm{T}_{10} 30 \%$ Bael Pulp & 15.57 & 14.90 & 14.47 & 01.10 & 8.9 & $*$ & $*$ & 1.5 \\
\hline 'F' test & Sig & Sig & Sig & - & & & & - \\
\hline $\mathrm{SE}(\mathrm{m}) \pm$ & 0.010 & 0.014 & 0.014 & - & & & & - \\
\hline $\mathrm{CD}$ at $5 \%$ & 0.030 & 0.042 & \begin{tabular}{l|}
0.041 \\
\end{tabular} & - & & & & - \\
\hline
\end{tabular}

* Spoilage

\subsection{Taste}

The data in respect of taste score of lime blended Bael syrup as influenced by different recipes at ambient storage condition was recorded upto 120 days of storage are presented in Table 2. The data exhibited that, the taste score of lime blended Bael syrup was decrease during storage period. The decrease in taste score of lime blended Bael syrup during storage might be due to many factors which affect storage stability of products and temperature play important role among them. Minimum decrease (9.0 to 8.6) in taste score was noticed in treatment $\mathrm{T}_{7}(30 \%$ Bael pulp $+10 \%$ lime juice). Similar results were reported by Bhatia et al. (1986) ${ }^{[2]}$ observed taste retained under cold storage however, off taste and degraded aroma were observed under room temperature. Decrease in taste score of stored guava pulp has been reported by Karla et al. $(1987)^{[8]}$.

\subsection{Flavour}

The data in respect of flavour score of lime blended Bael syrup as influenced by different recipes at ambient storage condition was recorded upto 120 days of storage are presented in Table 2. The data exhibited that, the flavour score of lime blended Bael syrup was decrease during storage period. The storage temperature had significant effect on flavour of lime blended Bael syrup. Minimum decrease (from 9.0 to 8.7) in flavour score was noticed in treatment combination $\mathrm{T}_{7}(30 \%$ 
Bael pulp $+10 \%$ lime juice). Similar results were reported by Jain et al. (1986) ${ }^{[7]}$ observed retention of flavour was better in all the three fruit squash stored at low temperature. Ghorai and Khurdiya (1998) ${ }^{[5]}$ observed the storage temperature had significant effect on the flavour.

\subsection{Overall acceptability}

The data in respect of overall acceptability of lime blended Bael syrup as influenced by different recipes at ambient storage condition was recorded upto 120 days of storage are presented in Table 3. The data exhibited that, the overall acceptability of lime blended Bael syrup was decrease during storage period. The storage temperature had significant effect on overall acceptability of lime blended Bael syrup. Minimum decrease (from 9.3 to 9.0) in overall acceptability was noticed in treatment $\mathrm{T}_{7}(30 \%$ Bael pulp $+10 \%$ lime juice). Similar results were reported by Kotecha and Kadam (2003) ${ }^{[9]}$ noted that, there was gradual decrease in the overall acceptability score of syrup stored at room temperature during the storage period of 180 days. Mishra et al. (2013) ${ }^{[10]}$ observed that the organoleptic quality of Bael candy was extremely good in polythene pouches up to four months while only one month in glass jar.

Table 2: Effect of storage conditions on taste score and flavour score

\begin{tabular}{|c|c|c|c|c|c|c|c|c|}
\hline \multirow{3}{*}{ Treatment } & \multirow{2}{*}{\multicolumn{3}{|c|}{\begin{tabular}{|c|} 
Taste Score \\
Storage period (days) \\
\end{tabular}}} & \multirow{3}{*}{ Total change in taste score } & \multicolumn{3}{|c|}{ Flavour score } & \multirow{3}{*}{ Total change in flavour score } \\
\hline & & & & & Storage & eriod & (days) & \\
\hline & Initial & $90^{\text {th }}$ & $120^{\text {th }}$ & & Initial & $\mathbf{9 0}^{\text {th }}$ & $120^{\text {th }}$ & \\
\hline $\mathrm{T}_{1} 25 \%$ Bael Pulp + 5\% lime Juice & 8.9 & $*$ & $*$ & 0.7 & 8.8 & $*$ & $*$ & 0.7 \\
\hline $\mathrm{T}_{2} 25 \%$ Bael Pulp + 7.5\% Lime Juice & 8.9 & $*$ & $*$ & 0.6 & 8.8 & $*$ & $*$ & 0.8 \\
\hline $\mathrm{T}_{3} 25 \%$ Bael Pulp + $10 \%$ Lime Juice & 9.0 & 8.8 & 8.5 & 0.5 & 8.9 & 8.7 & 8.5 & 0.4 \\
\hline $\mathrm{T}_{4} 25 \%$ Bael Pulp + $12.5 \%$ Lime Juice & 8.9 & 8.5 & 8.3 & 0.6 & 8.8 & 8.3 & 8.1 & 0.7 \\
\hline $\mathrm{T}_{5} 30 \%$ Bael Pulp + 5\% Lime Juice & 8.8 & $*$ & $*$ & 0.8 & 8.7 & $*$ & $*$ & 0.9 \\
\hline $\mathrm{T}_{6} 30 \%$ Bael Pulp + 7.5\% Lime Juice & 8.9 & 8.1 & $*$ & 0.8 & 8.8 & 8.0 & $*$ & 0.8 \\
\hline $\mathrm{T}_{7} 30 \%$ Bael Pulp + 10.\% Lime Juice & 9.0 & 8.9 & 8.6 & 0.4 & 9.0 & 8.8 & 8.7 & 0.3 \\
\hline $\mathrm{T}_{8} 30 \%$ Bael Pulp + 12.5\% Lime Juice & 9.0 & 8.6 & 8.3 & 0.7 & 8.9 & 8.3 & 8.2 & 0.7 \\
\hline $\mathrm{T}_{9} 25 \%$ Bael Pulp & 8.8 & $*$ & $*$ & 0.9 & 8.7 & $*$ & $*$ & 1.3 \\
\hline $\mathrm{T}_{10} 30 \%$ Bael Pulp & 8.7 & $*$ & $*$ & 1.1 & 8.6 & $*$ & $*$ & 1.5 \\
\hline
\end{tabular}

* Spoilage

Table 3: Effect of storage conditions on overall acceptability

\begin{tabular}{|c|c|c|c|c|}
\hline \multirow{3}{*}{ Treatment } & \multirow{2}{*}{\multicolumn{3}{|c|}{$\begin{array}{l}\text { Overall acceptability } \\
\text { Storage period (days) } \\
\end{array}$}} & \multirow{3}{*}{ Total change in overall acceptability } \\
\hline & & & & \\
\hline & Initial & $90^{\text {th }}$ & $120^{\text {th }}$ & \\
\hline $\mathrm{T}_{1} 25 \%$ Bael Pulp + 5\% lime Juice & 8.9 & $*$ & $*$ & 0.7 \\
\hline $\mathrm{T}_{2} 25 \%$ Bael Pulp + 7.5\% Lime Juice & 9.1 & $*$ & $*$ & 0.7 \\
\hline $\mathrm{T}_{3} 25 \%$ Bael Pulp + 10\% Lime Juice & 9.3 & 9.0 & 8.8 & 0.5 \\
\hline $\mathrm{T}_{4} 25 \%$ Bael Pulp + 12.5\% Lime Juice & 9.2 & 8.8 & 8.6 & 0.6 \\
\hline T $530 \%$ Bael Pulp + 5\% Lime Juice & 8.8 & $*$ & $*$ & 0.8 \\
\hline $\mathrm{T}_{6} 30 \%$ Bael Pulp + 7.5\% Lime Juice & 9.1 & 8.3 & $*$ & 0.8 \\
\hline $\mathrm{T}_{7} 30 \%$ Bael Pulp + 10.\% Lime Juice & 9.3 & 9.1 & 9.0 & 0.3 \\
\hline T 8 30\% Bael Pulp + 12.5\% Lime Juice & 9.2 & 8.3 & 8.2 & 0.7 \\
\hline T $925 \%$ Bael Pulp & 8.8 & $*$ & $*$ & 0.9 \\
\hline $\mathrm{T}_{10} 30 \%$ Bael Pulp & 8.6 & $*$ & $*$ & 1.0 \\
\hline
\end{tabular}

* Spoilage

\section{Conclusion}

For the investigation conducted on effect of different recipes on storage of lime blended Bael syrup following conclusions could be drawn.

The lime blended Bael syrup prepared with different recipes stored at ambient storage condition was found superior after 120 days of storage in ascorbic acid and sensory qualities. The minimum decrease found in ascorbic acid.

The Bael syrup prepared with 30 per cent Bael pulp blended with 10 per cent lime juice stored at ambient storage secured the highest score for colour, flavour, taste and overall acceptability as compared to other recipes.

\section{Reference}

1. Amerine MA, Pangborn RM, Roesler EB. Principles of sensory evaluation of food. Academic press, New York, 1965.

2. Bhatia BS, Siddappa GS, Girdharilal. Physico-chemical changes in jack fruit squash during storage. The Ind. J Agril. Sci. 1986; 24(4):405-413.
3. Dixit BBK, Dutta S. J Indian Chem. Soc. 1932; 9:271279.

4. Garg N, Preeti Yadav, Sanjay Kumar, Abhay Dikshit. Screening of Bael selections for preparation of sweet wine. Ind. J Hort. 2014; 71(1):99-103.

5. Ghorai K, Khurdiya DS. Storage of heat processed kinnow mandarin juice. J Food Sci. Tech. 1998; 35(5):422-424.

6. Gopalan CBV, Rama Sastri, Balasubramanian. In: Nutritive value of Indian food. National Institute of Nutrition, ICMR, Hyderabad, India, 1971.

7. Jain SP, Tripathi VK, Ram HB, Singh S. Effect of storage conditions on storage life of some important squashes, Part-II. Indian Food Packer. 1986; 30(3):25-27.

8. Karla SK, Tandon DK, Lohabi HC. Prevention of discoloration in guava beverage during storage. Indian Food Packer. 1987; 41(1):21-25.

9. Kotecha PM, Kadam SS. Preparation of ready-to-serve beverage, syrup and concentrate from tamarind. J Food Sci. Tech. 2003; 40(1):76-79. 
10. Mishra DK, Saroj PL, Pathak S. Effect of packaging containers on storage stability of Bael (Aegle marmelos Correa) candy under ambient conditions. Prog. Hort. 2013; 45(1):122-125.

11. Ranganna S. Analytical methods and FPO specification in Handbook of Analysis and quality control for fruit and vegetable products. $2^{\text {nd }}$ Ed. Tata Mcgraw - Hill Pub.Co., New Delhi, 1986, 1-101p.

12. Ranote PS, Saini SPS, Bawa AS. Evaluation of thermal process and shelf-life of Kinnow juice. J. Food Sci. Tech. 1995; 30(2):88-91.

13. Rathod AS, Shakya BR, Ade KD. Studies on Effect of Thermal Processing on Preparation of Bael Fruit RTS Blended with Aonla. IJREAT. 2014; 2(3):1-6.

14. Roy P, Mujumdar BC. Science and Cultivation. 1989; 55:110-111.

15. Waskar DP, Khurdiya DS. Processing and storage of phalsa beverages. Indian Food Packer. 1987; 41(5):7-23. 